\title{
VIRTUAL MODELLING AND LABORATORY RESEARCH OF PARAMETERS OF PLANTING UNIT'S WORKING PARTS
}

\author{
Vladimir Viktorovich KOSOLAPOV ${ }^{*}$, Elena Valentinovna KOSOLAPOVA ${ }^{1}$, \\ Denis Nikolaevich IGOSHIN ${ }^{1}$, Anatoly Nikolaevich SKOROKHODOV², \\ Alexander Alekseevich RUDENKO ${ }^{3}$ \\ ${ }^{1}$ Nizhny Novgorod State University of Engineering and Economics; Knyaginino; Nizhny Novgorod Region; Russia \\ ${ }^{2}$ Russian State Agrarian University - Moscow Timiryazev Agricultural Academy; Moscow; Russia \\ ${ }^{3}$ Togliatti State University; Togliatti; Samara Region; Russia
}

\begin{abstract}
Research relevance is determined by the need of agricultural producers of Nizhny Novgorod Region to increase the profitability of sugar beet cultivation and to reduce seed losses at sowing. Another important factor is optimal energy efficiency of sowing machines, which can be achieved by reducing the draft force input required to operate the working parts. Leading approach to the research of this issue is to conduct a multifactorial laboratory experiment, taking into account several factors that have the greatest influence on the process of interaction of working parts with the soil. Virtual simulation methods were applied with use of Computer-Aided Engineering (CAE) FlowVision ${ }^{\circledast}$ (TESIS Group) engineering analysis system, allowing creation of close-to-real controlled conditions. Relationships between the lift angle and the span angle of a duckfoot opener were identified; influence of soil moisture content, speed of working parts and their working depth on draft force input and quality of the formed seedbed was determined with justification of their optimal combination. Presented technology and the planting unit assure the technological process quality, they are of practical value for agricultural and engineering companies, as well as for research institutes for design of modern agricultural machinery.
\end{abstract}

Keywords: virtual simulation; planting unit; laboratory research; energy saving; planter

Increasing crop yields is a priority task in the general paradigm of increasing the profitability of agro-industrial production. This indicator is mainly influenced by the quality of sowing operations, technological operations and machinery involved in the process. It is important to place seeds at the boundary of two soil layers: the lower wet layer to ensure faster root emergence, and the upper loosened layer for supplying oxygen and moisture volatility reduction.

During surveys made in six different fields of Nizhny Novgorod Region during sugar beet sowing, it was revealed that up to $8 \%$ of sown seeds remained unburied. This is primarily due to poor quality of pre-sowing soil tillage and imperfection of working parts of sowing machines. In this context, there was a need to develop a seed sowing technology and a plating unit for independent furrowing with subsequent creation of seedbed with densified bottom and walls to ensure an increase in sowing precision. Furthermore, the unit should loosen the lifted soil layer and then lay it back into operating space.

Improving the quality of sugar beet sowing and reducing its energy costs at the same time is an actual problem.

Many researchers have been engaged in solving the problem of planting crop seeds to a strictly defined depth. Importance of precision sowing has been closely observed in works by Upadhyaya and Gowda (2017), Azad et al.
(2011). Automation of the depth regulation process has been described by Finnish scientists Suomi et al. (2009), who proposed a mechanism for regulation of sowing depth, as well as its gauging system. A group of scientists (Adamchuk et al., 2004) proposed a new machinery design using modern tools to obtain a high qualitative level of operations and to maximize harvest potential.

Sudduth et al. (2003) studied the possibility of using a system of sensors for reading of soil electrical conductivity in order to further improve the sowing quality by determining the agronomic parameters of the processed material (soil). In addition to the precise placement of seeds and high-quality soil preparation, it is necessary to take into account sowing time, which is an important issue according to Benoit et al. (2015).

The issues of profitability increasing of agricultural production have also been considered by multiple scientist (Leea et al., 2010; Suomi and Oksanen, 2015; McBratney et al., 2004; Stone et al., 2008; Skuriatin and Bondarev, 2008).

An equally important role is played by research aimed at improving agro-technical parameters of sugar beet cultivation, speed modes (Ermakov, 2013; Repetov and Ermakov, 2012), sowing depths and precision sowing (Kosolapov et al., 2016), as well as technological modes (Bulgakov et al., 2017). 


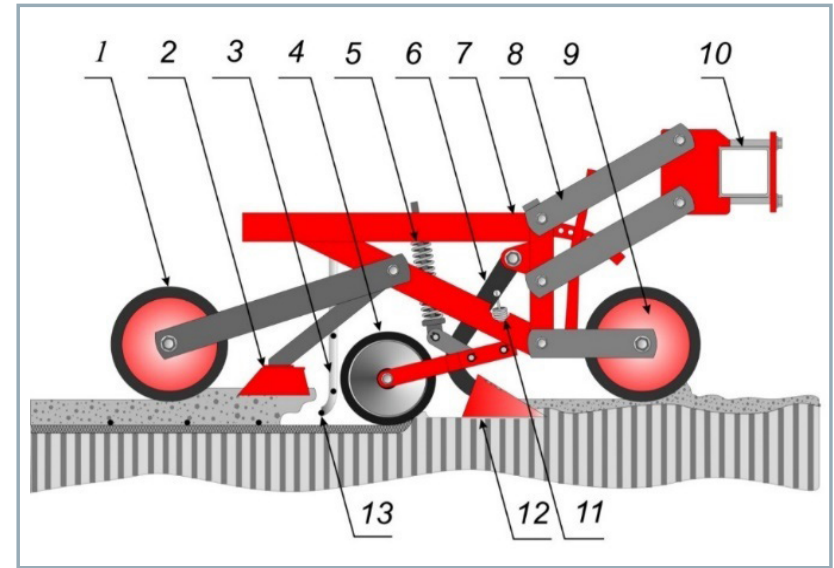

Fig. 1 Design and operation scheme of the planting unit

To improve the quality of sugar beet planting, the authors developed a modernized soil opener mechanism; its novelty is confirmed by a utility model patent no. 118163 (Kosolapov et al., 2016).

A planting unit (Fig. 1) consists of a frame [7] with the following elements mounted upon it: L-shaped stand [6] with a duckfoot opener [12]; safety spring [5]; press wheel [4] which is pressed against the soil by spring [11]; coverers [2]; packer wheel [1]. Planting depth is adjusted by depth wheel [9]. The unit is fixed to the frame of a drill seeder [10] using a parallel link mechanism [8]. Design of the planting unit can be modified to ensure simultaneous mineral fertilization during sowing (Kosolapov et al., 2016).

Proposed design should provide the sowing technology, novelty of which is confirmed by the patent for invention no. 2494595 Method for Row Crops Planting (Kosolapov et al., 2016), which minimizes the influence of pre-sowing soil preparation quality, and partially relinquishes the use of this operation in the future. Technological process includes: opening the furrow to the base depth (Fig. 2a) - soil is not compacted, but thrown out towards the sides along the row, creating a relatively flat surface without lumps and retaining the capillary structure; formation of the groove up to the sowing depth (Fig. 2b), soil crumbling due to its compacting next to the groove is avoided by densification of its bottom and walls; planting seeds along the groove (Fig. 2c); furrow closing with the loosened layer of soil (Fig. 2d); surface compaction (Fig. 2f) in order to increase the area of seed-to-soil contact.

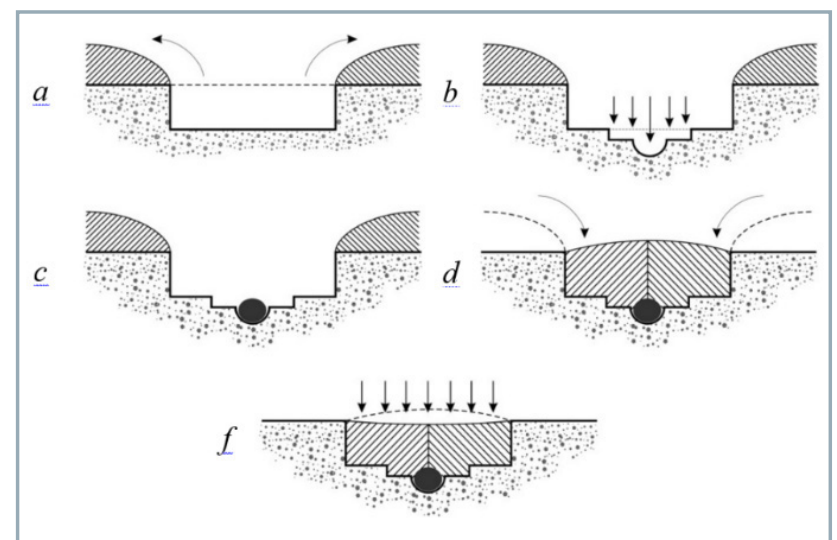

Fig. 2 Seed covering process
Covering of seeds by loosened soil prevents evaporation of moisture and provides seeds with air at the same time, what also has a favourable effect on their germination. Soil under the seeds quickly restores its capillary structure, contributing to early root emergence and an increase in the uniformity of field germination.

In the course of theoretical calculations, geometry variation limits of the planting unit working parts were identified, on the basis of which virtual test models were created (Skorokhodov and Kosolapov, 2013).

In order to confirm theoretical research, as well as to reduce the number of laboratory tests, finite volume method of FlowVision ${ }^{\circledast}$ software package was proposed.

To solve the stated issues, we applied the method of numerical solution to the continuous media dynamics equation presented by Mudarishov et al. (2008).

Advantage of this method lies in the complete isolation of the tested virtual model from external factors with regards to provision of identical conditions for all types of working parts and visual observations in question.

We designed working part models for the planting unit using the SolidWorks ${ }^{\circledR}$ (Dassault Systems) 3D CAD system. According to theoretical calculations, the following wedge face angles faces were subjected to change: angle of crumpling $\beta d f$, span angle of the cutting edges $\gamma d f$, and lift angle (angle of attack) adf. Kosolapov (2013) showed that pressure exerted on the surface of a dihedral wedge will decrease with decreasing of the aforementioned angles in relation to the seedbed.

Work by Kurdyumov et al. (2015) was taken as a basis for determining the optimal variation limits in the design parameters of the working part, as well as in technological parameters of the medium being treated.

Therefore, we can distinguish the following research objectives:

1. to carry out a virtual research of the designed working part in order to obtain graphical and numerical dependencies of its interaction with the processed environment;

2. to determine optimal geometric parameters of the duckfoot opener with the subsequent manufacturing of the prototype in its actual size;

3. to conduct laboratory tests in order to obtain optimal operating parameters of the unit.

\section{Material and methods}

The first research stage is virtual simulation. Process of virtual modelling was carried out using FlowVision ${ }^{\circledR} \mathrm{CAE}$ system, in which a design area was completely simulating the actual tillage bin. Designed models were imported into the design area with a possibility to vary the depth of their immersion relative to the separated media, as well as velocity and density of the processed material. We assigned mathematical equations characterizing the considered material, as wells as boundary conditions for the surfaces of the working parts.

For the modelling, subsequent calculation and visualization of the ongoing processes, volume of fluid (VOF) method for tracking the free surface motion was used; 
turbulence equations were disabled; vortex, compressibility and surface tension equations were not taken into account (Kosolapov et al., 2016).

A calculation grid consisting of 384,670 cells was superimposed on the design area and model, while the second level adaptation was applied to the boundaries of the working part surface to increase the calculation accuracy of the parameters being read.

As the criteria for assessing the performance of the duckfoot opener, we adopted the parameters that make it possible to obtain a values of the pressure exerted on the surface of the wedge, pressure in the volume of the working medium, trajectories of soil particles, etc. (Fig. 3).

Analysis of the obtained results was carried out using the FlowVision ${ }^{\circledast}$ post-processing software tools, based on the analysis of data created in the super-groups and 'phase volume'-space layers, 'colour contours'-pressure, 'isolines'pressure, etc.

In this case, main evaluation parameter was the pressure created inside the soil medium and directly exerted on the wedge surface.

Calculation was carried out in a vertical longitudinal section at a distance of $40 \mathrm{~mm}$ from the opener line of movement.

For statistical analysis of the results obtained, Portable Statgraphics Centurion ${ }^{\circledR}$ 15.2.11 (Statpoint Technologies, Inc.) software package was used (specifically for calculation of regression coefficients and their significance determination, validity checks of models and plotting of response surfaces).

Before the simulation, an experimental factor matrix was compiled, where $x_{1}$ represents the lift angle and $x_{2}$ represents the span angle of a duckfoot type furrow opener. We adopted the dynamic pressure $P$ and the quality of seedbed formation $K$ as the optimization criteria.

The second research stage is the laboratory tests. For laboratory research, a prototype of the planting unit with the considered working parts was created.

Laboratory research was carried out using a specialized laboratory installation (Figs. 4a and 4b), which consisted of the bin filled with soil [5], support rails to move the trolley

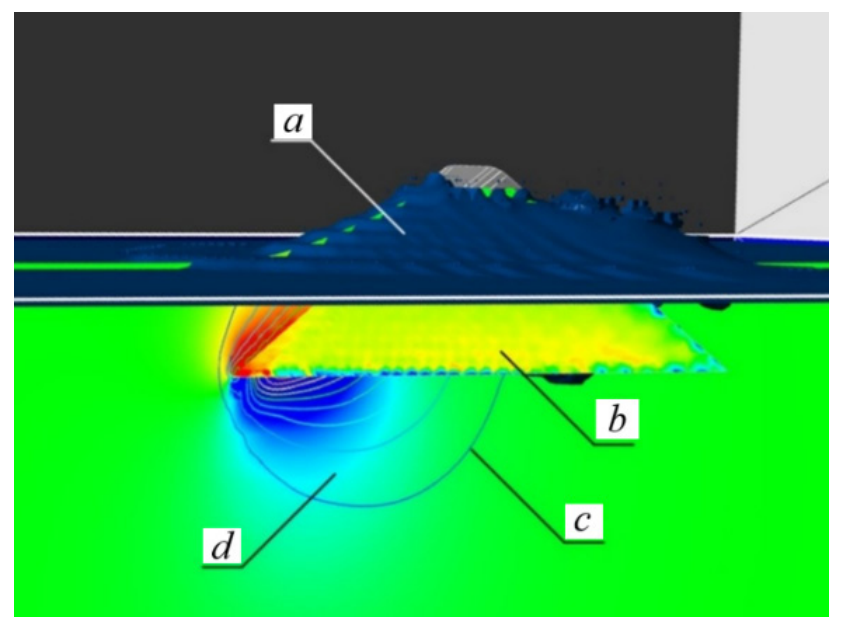

Fig. 3 Calculated parameters

$a$ - motion pattern of particles; $b$-dynamic pressure on the wedge surface; $c$ - isolines in a horizontal plane; $d$ - pressure produced in the medium in a horizontal plane
Table $1 \quad$ Experimental factor matrix

\begin{tabular}{|l||c|c|c|c|}
\hline \multirow{2}{*}{ Factor } & Code & \multicolumn{3}{|c|}{ Variation level } \\
\cline { 3 - 5 } & number & $\mathbf{- 1}$ & $\mathbf{0}$ & $\mathbf{+ 1}$ \\
\hline \hline Lift angle, deg. & $X_{1}$ & 30 & 45 & 60 \\
\hline Span angle, deg. & $X_{2}$ & 40 & 60 & 80 \\
\hline
\end{tabular}

[8] with the fixed prototype [9]. Trolley was driven by the electric motor [1] through the gearbox [2] and the V-belt drive [3]. When working, the drum [4] winds in the cable [6] connected to the trolley through the dynamometer of DPU type [7].

Physical and mechanical properties of the soil were selected to resemble as close as possible the soil properties of the central part of Nizhny Novgorod Region.

During the laboratory tests, the following parameters were measured: draft force input for the unit; distance covered by the working part; unit speed, depth of the working part; furrow profile, moisture content and density of soil.

The experiments involved: tillage bin - a laboratory installation of the Agricultural Machinery Department of Volgograd State Agrarian University; $1 \mathrm{~m}$ long metal ruler (according to GOST 427-75 for determining the linear dimensions); boxes (according to GOST 23932 for soil sampling); SHSU drying cabinet for drying samples; electronic scales VST 300/10; SM200 soil moisture sensor

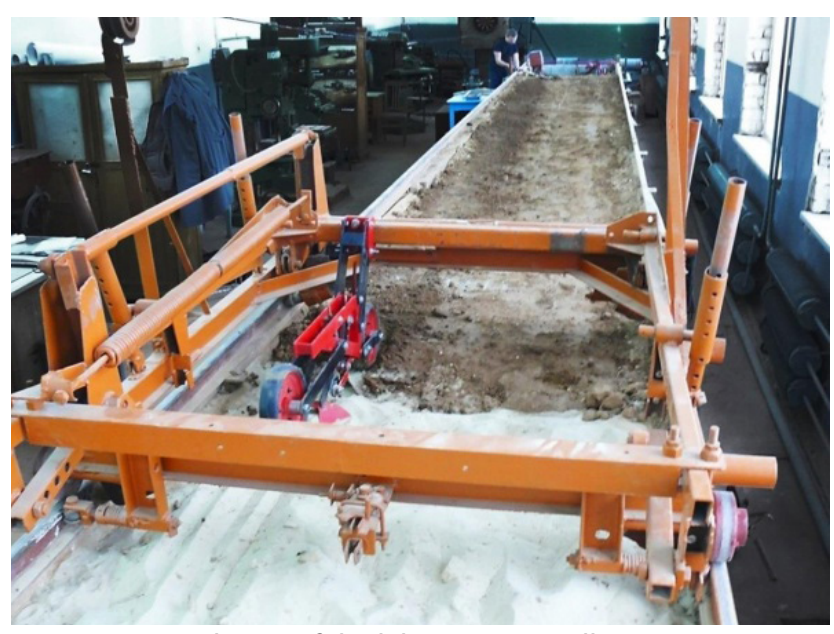

Fig. 4a General view of the laboratory installation

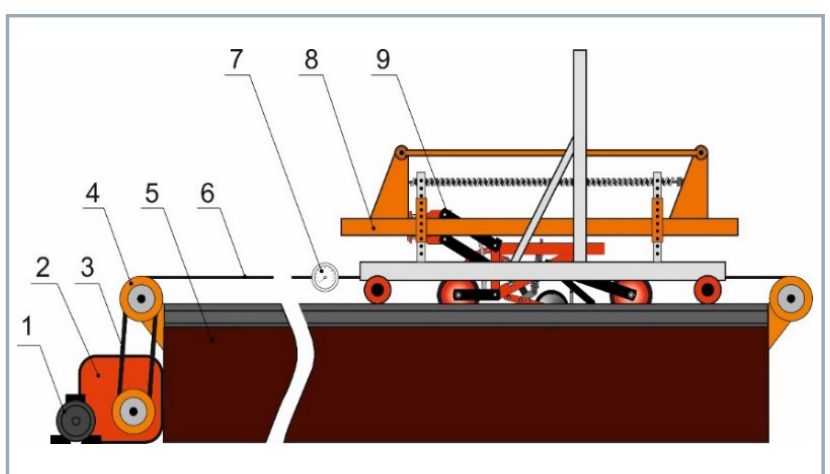

Fig. 4b Scheme of the laboratory installation 
produced by Delta-T Devices Ltd. for direct measurement of soil moisture; DPU 5-2 dynamometer for determination of draft force input.

We performed comparative tests of the proposed design of duckfoot type furrow opener with a production version of chisel type furrow opener. For making accurate measurements, proposed duckfoot type furrow opener and the production chisel type furrow opener were alternately placed on the same planting unit (Fig. 5).

During the formation of the sowing bed, the considered working part was to ensure an optimal and uniform planting depth and density of soil at the furrow bottom, as well as to retain soil moisture after the furrow was covered with soil layer.

Technique for planning the experiment was based on Box-Behnken non-positional plan.

To optimize the parameters and operating modes, we adopted the Mathematical Theory of Optimal Experiment.

Based on a priori ranking, the most significant were the following factors:

1. operating speed of the unit $v, m \cdot s^{-1}$, selected limits were limited by the technical capabilities of the laboratory stand - from 2 to $12 \mathrm{~km} \cdot \mathrm{h}^{-1}$ (from 0.55 to $3.33 \mathrm{~m} \cdot \mathrm{s}^{-1}$ );

2. working depth of planting $h, \mathrm{~mm}$, it was selected according to the technological requirements for the cultivation of sugar beet, $h=3-7 \mathrm{~cm}$;

3. soil moisture content $W, \%$, it was selected within the range of $15-35 \% \pm 4 \%$.

The average values of draft force input for the planting unit as the criterion for quality assessment were taken. This criterion is universal and allows for estimation of energy costs that arise during operation of the planting unit, as well as the stability of furrow formation process, estimated by linearity of furrow, and the working depth factor, determining the quality and stability of planting:

$$
k_{\mathrm{wdf}}=1-\left(\frac{h_{\mathrm{w}}-h_{\mathrm{m}}}{h_{\mathrm{w}}}\right)
$$

where:

$h_{w} \quad$ - working depth of planting determined by the depth wheel, $m$

$h_{m} \quad$ - actual depth of planting measured after the experiment, $\mathrm{m}$
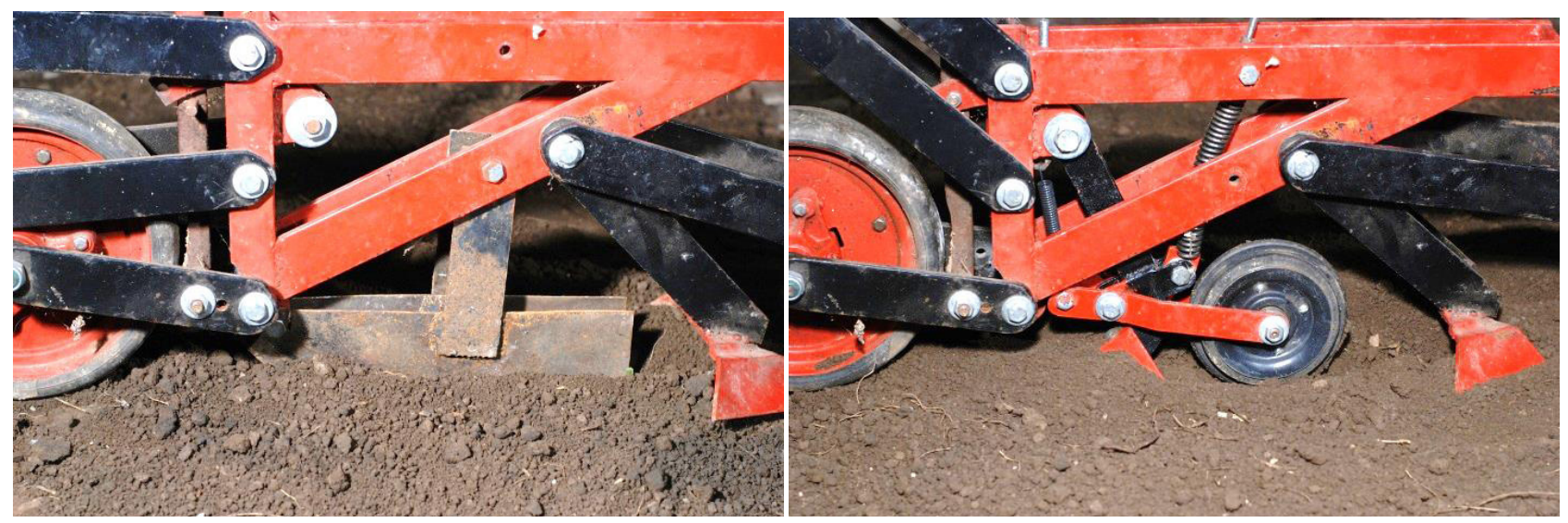

Fig. 5 Planting unit with a duckfoot type furrow opener (left) and a production chisel type furrow opener (right)
On the basis of the aforementioned, a matrix of factor variation (Table 2) was created. When using non-composition plans of the second order (Box-Behnken, Hartley, etc.), the factors can be of three levels: upper $(+1)$, main $(0)$ and lower $(-1)$.

Number of experiments, as a rule, is determined by the equation:

$$
N=2^{m}
$$

where:

$m \quad$ - number of factors

In order to obtain regression equations, we used Portable Statgraphics Centurion ${ }^{\circledR}$ 15.2.11.0 software package to process the data. Obtained graphical dependencies were recorded in the form of response surfaces and their 2D cross sections, as well as regression equations corresponding to these surfaces.

\section{Results}

On the basis of results from virtual experiment, we obtained regression models describing the influence of the considered factors on the optimization criteria.

In the first case, in determining influence of the factors on pressure, we obtained the following regression equation (with a 95\% confidence level) after excluding insignificant coefficients:

$$
\begin{gathered}
P=-1,569.44+14.4444 x_{1}+47.5 x_{2}-0.481481 x_{1}^{2}+ \\
+1.0833 x_{1} x_{2}-0.395833 x_{2}^{2}
\end{gathered}
$$

Validity of the obtained $R^{2}$ model approximation is $97.49 \%$. For graphical analysis of the regression model, we created a $3 \mathrm{D}$ response surface model to determine the influence of the factors on the optimization criterion $P$. It can be seen that an increase in $P$ criterion occurs with increasing $x_{1}$ and $x_{2}$ factors, which can be explained by an increase in the vertical component of pressure (Fig. 6).

Analysing the influence of these factors on the unobstructed seedbed optimization criterion with a $95 \%$ confidence level, the regression equation can be written as: 
Table 2 Planning matrix of the factor experiment

\begin{tabular}{|l||c|c|c|c|}
\hline \multirow{2}{*}{ Factor } & Code number & \multicolumn{3}{|c|}{ Variation level } \\
\cline { 3 - 5 } & & $-\mathbf{1}$ & $\mathbf{0}$ & $\mathbf{+ 1}$ \\
\hline \hline Speed of the unit $\boldsymbol{v}\left(\mathbf{m}^{-\mathbf{s}^{-1}}\right)$ & $x_{3}$ & 0.55 & 1.83 & 3.33 \\
\hline Soil moisture content $\boldsymbol{W}(\mathbf{\%})$ & $x_{4}$ & 15 & 25 & 35 \\
\hline Working depth of planting $\boldsymbol{h}(\mathbf{m})$ & $x_{5}$ & 0.03 & 0.05 & 0.07 \\
\hline
\end{tabular}

$$
\begin{gathered}
K=-312.714-6.42381 x_{1}-1.94286 x_{2}+0.0384127 x_{1}^{2}+ \\
+0.012381 x_{1} x_{2}+0.00535714 x_{2}^{2}
\end{gathered}
$$

Validity of the obtained $R^{2}$ model approximation is $98.01 \%$. For graphical analysis of the regression model, we created a 3D response surface model to determine the influence of the factors on the optimization criterion $\mathrm{K}$. It can be seen that an increase in $K$ criterion, i.e. an increase in the number of particles trapped in the working zone of press wheel, occurs with decreasing $x_{1}$ and $x_{2}$ factors (Fig. 7).

Visualization and analysis of the processes occurring in the working environment during the duckfoot opener movement were performed along cross sections in vertical and horizontal planes - along the length and height of the opener (Fig. 8).
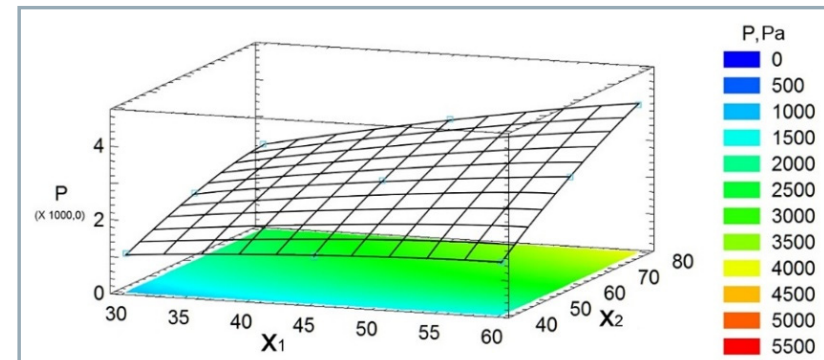

Fig. 6 Relationship of pressure $(P)$ versus lift angle $\left(X_{1}\right)$ and span angle $\left(X_{2}\right)$

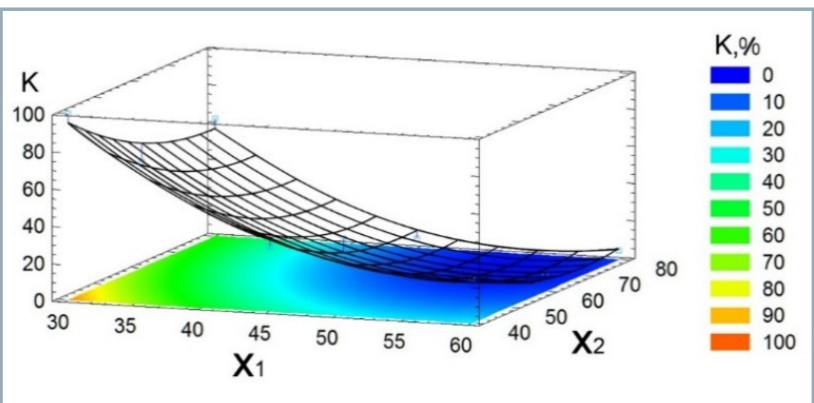

Fig. 7 Relationship of volume of soil particles trapped at the bottom of the furrow versus lift angle $\left(X_{1}\right)$ and span angle $\left(X_{2}\right)$

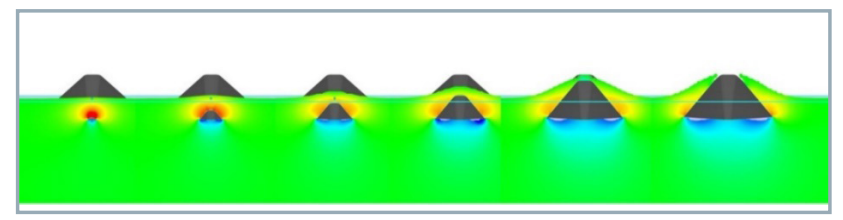

Fig. 8 Scalar field of pressure in the cross sections of the opener
In regards to aforementioned conditions, we selected an acceptable geometry of the opener in question by reducing the received response surfaces to a $2 \mathrm{D}$ section of the model (Fig. 9).

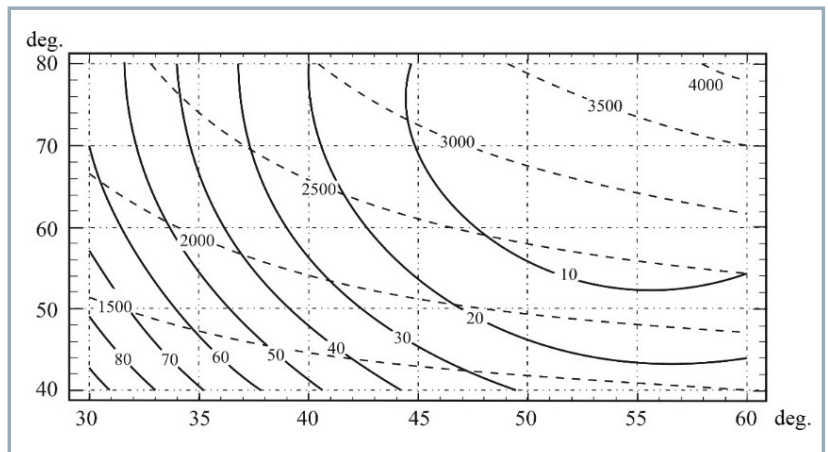

Fig. 9 Combining 2D sections to determine the optimal geometry of the duckfoot opener with required parameters
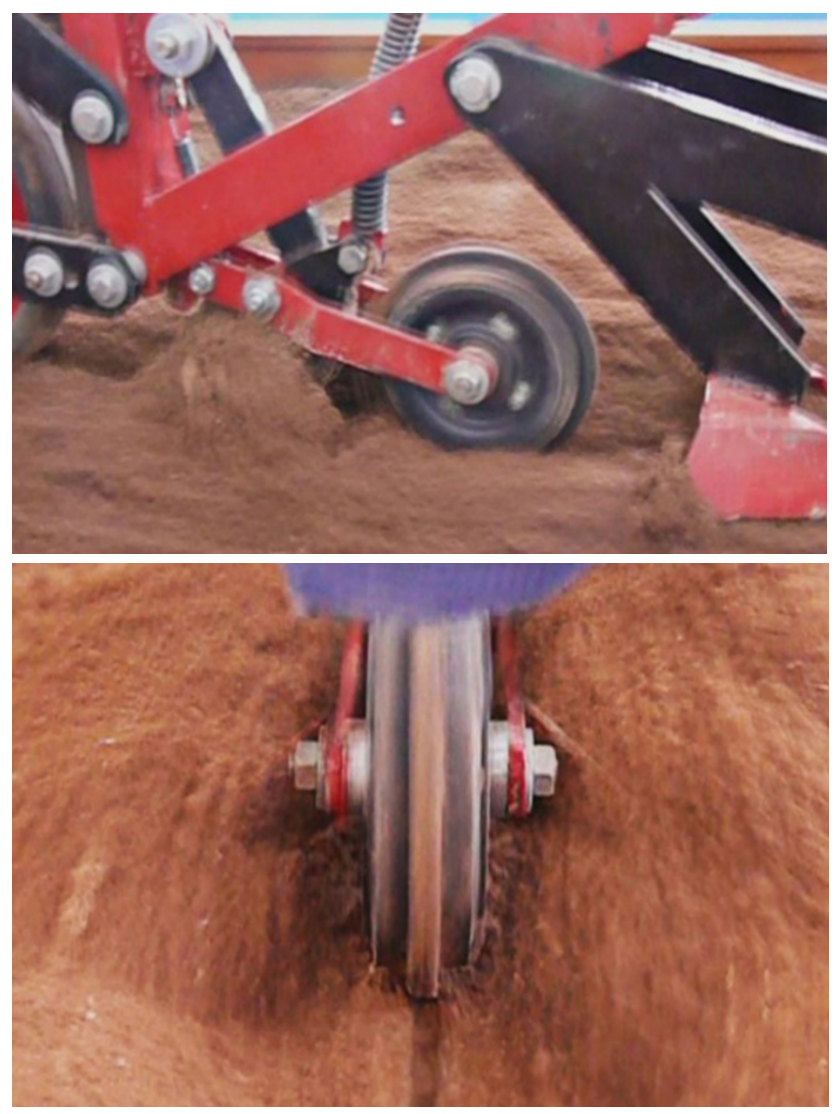

Fig. 10 Research of the furrow formation process 


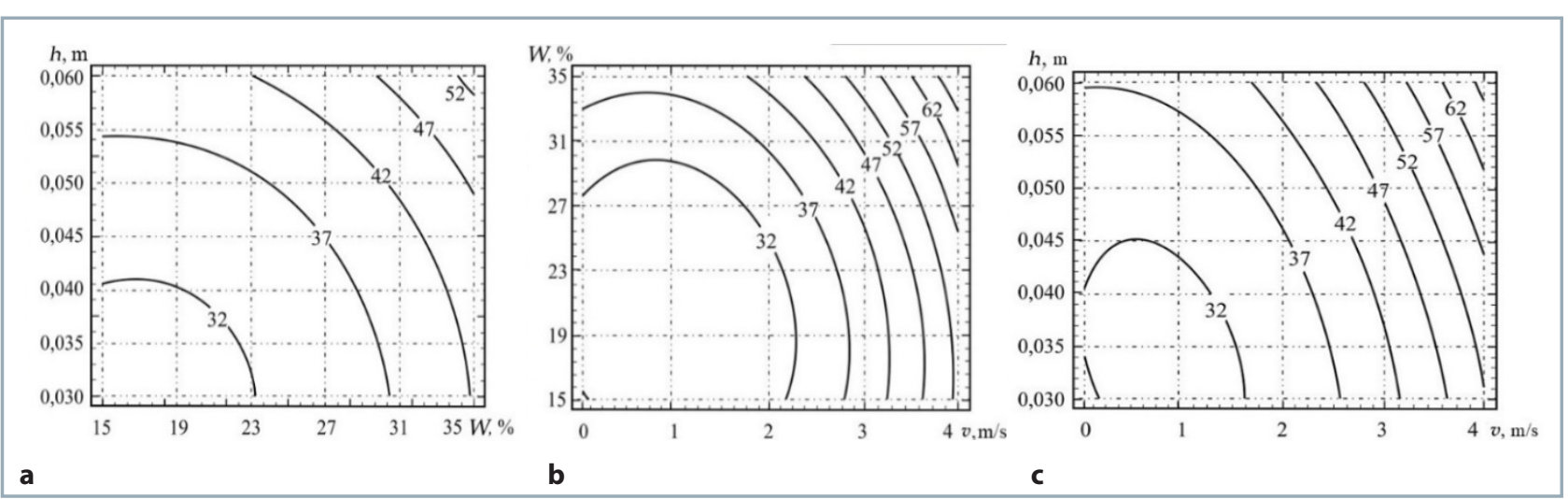

Fig. $112 \mathrm{D}$ cross-section model depicting the changes of draft force input for the soil opener

a - soil moisture content and depth of planting; $b$ - soil moisture content and speed of planting; $c$ - speed and depth of planting

Results show that the smaller the opener lift angle, the lower the dynamic pressure exerted on its working surface; therefore, at angles of $60^{\circ}$ and $80^{\circ}$, the pressure was equal to $3,985 \mathrm{~Pa}$, and at the minimum angles $-1,087 \mathrm{~Pa}$, respectively.

Considering the virtual test results, it is possible to recommend the following values of the considered factors: lift angle $\left(x_{1}\right)$ of $40-45^{\circ}$; span angle $\left(x_{2}\right)$ of $60-70^{\circ}$. In such manner, it is possible to obtain the average pressure value from 2.0 to $2.5 \mathrm{kPa}$, at which $15-20 \%$ of soil particles are trapped at the bottom of the furrow.

Photo and video materials (Fig. 10), as well as numeric data from the measuring equipment were obtained from performed laboratory research.

As a result of the experiments, we obtained graphical representations of influence of the aforementioned factors on draft force input in form of response surfaces, 2D sections, regression equations and their subsequent analysis.

When determining influence of the factors on draft force input, after excluding insignificant coefficients, we obtained (with a 95\% confidence level) the following regression equation:

$$
\begin{aligned}
R=25.5639- & 5.82667 x_{3}-0.094 x_{4}-95.5 x_{5}+x_{3}^{2}+ \\
+0.133333 x_{3} x_{4}+ & 100.0 x_{3} x_{5}+0.0075 x_{4}^{2}+2.5 x_{4} x_{5}+ \\
+ & 3,125.0 x_{5}^{2}
\end{aligned}
$$

Coefficient of variation of the obtained regression equation is 0.9249 . Analysing the obtained response surfaces (Fig. 11), it is possible to trace an increase in dynamics of draft force input with increasing soil moisture content $x_{4}$ and seeding depth $x_{5}$, which can be explained by an increase in the coefficient of friction and an increase in the contact area between the wedge working surface and soil. In this case, main influence is stipulated by soil moisture content. A change in the working depth does not significantly influence the draft force input for the working part up to a depth of $0.05 \mathrm{~m}$, but with increasing depth values, the processes characteristic for working parts of subsoil broadcast sowing begin. With an increase in the opener unit working speed over $2.5 \mathrm{~m} \cdot \mathrm{s}^{-1}$, there is an increase in the draft force input and in the energy with which soil particles are thrown away from the longitudinal axis of the opener.

\section{Conclusion}

Summarizing the research results, we can draw the following conclusions:

1. On the basis of obtained theoretical calculations and results from virtual research, a test piece for the proposed planting unit was created.

2. In terms of results of virtual tests, optimal values for the inclination angles of the duckfoot type furrow opener were obtained. These are: lift angle $\alpha_{d f}-40-45^{\circ}$; span angle $\gamma_{d f}-60-70^{\circ}$.

3. We performed laboratory tests, which made it possible to determine relationships of draft force input versus soil moisture content, working depth, and speed. Optimum level of soil moisture content for sowing is within the range of $18-23 \%$. Unit speed at a $23 \%$ moisture level should not exceed $2.5-3 \mathrm{~m} \cdot \mathrm{s}^{-1}$. With an increase in sowing depth by more than $0.05 \mathrm{~m}$, speed of the planting unit should not exceed $2.0-2.5 \mathrm{~m} \cdot \mathrm{s}^{-1}$.

In the course of comparative tests, we observed a 20-25\% decrease in draft force input for the proposed duckfoot type furrow opener compared to chisel type furrow opener. This allows utilization of the considered opener in terms of increasing energy efficiency, substantiating the need of its field testing.

Obtained results can be used by agricultural and engineering companies engaged in the production or modernization of planting units, as well as R \& D institutes for development of modern agricultural machinery.

The further research will be aimed at increasing the number of regions for possible implementation of the considered unit, taking into account physical and mechanical properties and composition of soils.

It is planned to modernize design of the planting section with inclusion of mechatronic components and automatic soil analysis systems.

\section{Abbreviations}

GOST - state standard

SHSU - universal drying cabinet

VST - fixed scales

DPU - universal spring dynamometer 


\section{References}

ADAMCHUK, V. I - SKOTNIKOV, A. V. - SPEICHINGER, J. D. - KOCHER, M. F. 2004. Development of an instrumented deep-tillage implement for sensing of soil mechanical resistance. In Transaction of the ASAE, vol. 47, no. 6, pp. 1913-1919.

AZAD, Md. S. - MANIK, M. R. - HASAN, Md. S. - MATIN, Md. A. 2011. Effect of different pre-sowing treatments on seed germination percentage and growth performance of Acacia auriculiformis. In Journal of Forestry Research, vol. 22, pp. 183-188.

BENOIT, D. - FIEUZAL, R. - RIVERA, M. A. - EZZAHAR, J. - JARLAN, L. RODRIGUEZ, J. C. - HAGOLLE, O. - WATTS, C. 2015. Impact of sowing date on yield and water use efficiency of wheat analyzed through spatial modeling and Formosat-2 images. In Remote Sensing, vol. 7, pp. 5951-5979.

BULGAKOV, V. - ADAMCHUK, V. - NADYKTO, V. - KYURCHEV, V. - NOZDROVICKÝ, L. 2017. Theoretical consideration of the controllability indicator of machine-tractor unit movement. In Acta Technologica Agriculturae, vol. 20, no. 1, pp. 11-18.

ERMAKOV, V. V. 2013. Results of experimental research on planting sugar beet at various speeds. In Bulletin of Kursk State Agricultural Academy, no. 7, pp. 75-77. (In Russian: Rezul'taty eksperimental'nykh issledovaniy pri poseve sakharnoy svekly na razlichnykh skorostyakh).

KOSOLAPOV, V. V. 2013. Choice and justification of geometric parameters of press wheel. In Bulletin of NNIIE, vol. 24, no. 4. (In Russian: Vybor i obosnovaniye geometricheskikh parametrov prikatyvayushchego borozdoobrazuyushchego kolesa).

KOSOLAPOV, V. V. - KOSOLAPOVA, E. V. - SKOROKHODOV, A. N. - VANDYSHEVA, M. S. - IGOSHIN, D. N. 2016. Development of technology and means for application of mineral fertilizers in sugar beet growing. In Bull. of NGIER, vol. 61, no. 6, pp. 53-59. (In Russian: Razrabotka tekhnologii i sredstva vneseniya mineral'nykh udobreniy pri vozdelyvanii sakharnoy svekly).

KURDYUMOV, V. I. - ZYKIN, E. S. - TATAROV, G. L. 2015. Optimization of parameters and operation modes for multi-level soil opener. In Bulletin of Ulyanovsk State Agricultural Academy, vol. 32, no. 4, pp. 195-200. (In Russian: Optimizatsiya parametrov i rezhimov raboty soshnika dlya raznourovnevogo vyseva semyan i udobreniy). LEEA, S. - ALCHANATISB, V. - YANGC, C. - HIRAFUJID, M. MOSHOUE, D. - LI, C. 2010. Sensing technologies for precision specialty crop production. In Computers Electronics in Agriculture, vol. 74, pp. 2-33.

MCBRATNEY, A. - WHELAN, B. - ANCEV, T. 2004. Future directions of precision agriculture. In Precision Agriculture, vol. 6, pp. 7-23. Invited paper, $7^{\text {th }}$ International Conference on Precision Agriculture, Minneapolis, USA.
MUDARISHOV, S. G. - MUFTEYEV, V. G. - MARDANOV, A. R. FARKHUTDINOV, I. M. 2008. CAD modeling of working surface. In Proceedings of the International Academy of Agrarian Education, no. 7, pp. 37-40. (In Russian: Modelirovaniye rabochey poverkhnosti pluga $v$ SAPR).

REPETOV, A. N. - ERMAKOV, V. V. 2012. Determination of parameters for sugar beet planting unit. In Bulletin of Kursk State Agricultural Academy, vol. 1, no. 1, pp. 118-119. (In Russian: Opredeleniye parametrov agregata dlya poseva sakharnoy svekly).

SKOROKHODOV, A. N. - KOSOLAPOV, V. V. 2013. Theoretical studies of force system exerted on planting unit with modernized soil opener for row crops planting. In XVII International Scientific and Practical Conference of Students and Young Scientists 2013, pp. 20-27. (In Russian: Teoreticheskiye issledovaniya sistemy sil, deystvuyushchikh na posevnuyu sektsiyu s modernizirovannoy soshnikovoy gruppoy dlya poseva propashnykh kul'tur).

SKURIATIN, N. F. - BONDAREV, A. V. 2008. Research of energyefficient method of planting grain crops. In Polytechnical Network Electronic Scientific Journal of Kuban State Agrarian University, no. 42. pp. 30-44. (In Russian: Izyskaniye energosberegayushchego sposoba poseva zernovykh kul'tur).

STONE, M. L. - BENNEWEIS, R. K. - BERGEIJK, J. VAN. 2008. Evolution of electronics for mobile agricultural equipment. In Transactions of the ASABE, vol. 51, no. 2, pp. 385-390.

SUDDUTH, K. A. - KITCHEN, N. - BOLLERO, G. - BULLOCK, D. 2003. Comparison of electromagnetic induction and direct sensing of soil electrical conductivity. In Agronomy Journal, vol. 95, no. 3, pp. 472-482.

SUOMI, P. - OKSANEN, T. - OJANNE, A. - KALMARI, J. - LINKOLEHTO, R. - TEYE, F. 2009. Automatic working depth control for seed drill using ISO 11783 compatible tractor. In Precision Agriculture 2009 Papers Presented at the $7^{\text {th }}$ European Conference on Precision Agriculture, ECPA 2009.

SUOMI, P. - OKSANEN, T. 2015. Automatic working depth control for seed drill using ISO 11783 remote control messages. In Computers and Electronics in Agriculture, vol. 116, pp. 30-35.

UPADHYAYA, S. V. - GOWDA, V. V. 2017. A review on agricultural seed sowing. In International Journal of Innovative Research in Science, Engineering and Technology, vol. 6, no. 4, pp. 7216-7223. 